\title{
Evaluation of Etiological Causes of Hematuria in Children
}

\section{Çocukluk Çağı Hematüri Olgularında Etiyolojik Nedenlerin İncelenmesi}

\author{
Mehmet Emre ARI ${ }^{1}$, Sare Gulfem OZLU², Gulay DEMIRCIN³ , Aysun CALTIK YILMAZ", \\ Ozlem AYDOG ${ }^{5}$, Mehmet BULBUL6
}

${ }^{1}$ Mehmet Emre ARl; University of Health Sciences, Dr Sami Ulus Childrens and Maternity Training and Research Hospital;

Department of Pediatric Cardiology, Ankara, Turkey

${ }^{2}$ Ankara Yildirim Beyazit University, Faculty of Medicine Department of Pediatric Nephrology, Ankara, Turkey

${ }^{3}$ TOBB ETU University, Faculty of Medicine, Department of Pediatric Nephrology, Ankara, Turkey

${ }^{4}$ Keçiören Training and Research Hospital, Department of Pediatric Nephrology, Ankara, Turkey

${ }^{5}$ Ondokuz Mayıs University, Faculty Of Medicine Department of Pediatric Nephrology, Samsun, Turkey

${ }^{6}$ University of Health Sciences, Dr Sami Ulus Childrens and Maternity Training and Research Hospital, Department of Pediatric

Nephrology, Ankara, Turkey

\begin{abstract}
Objective: Hematuria is an important and common sign of urinary system diseases in children. Careful assessment is needed for definitive diagnosis and appropriate management. In this study we aimed to investigate the demographic and clinical characteristics of patients who were admitted to our pediatric nephrology clinic with hematuria and to determine the features that will guide the diagnosis.
\end{abstract}

Material and Methods: Medical charts of 370 patients who were referred to our clinic in a period of four years with gross/macroscopic or microscopic hematuria were evaluated retrospectively. Demographical data, clinical and laboratory findings, imaging modalities and diagnosis of the patients were investigated.

Results: Of the patients 195 (52.7 \%) were boys and 175 (47.3\%) were girls and the majority of the patients were in the age group of 6-10 years. Two hundred and thirty-four (\%63.2) of the patients had macroscopic hematuria and 44 (15.3\%) had glomerular hematuria. Non-glomerular causes were found to be significantly higher among patients with macroscopic hematuria ( $p=0.002$ ). Acute poststreptococcal glomerulonephritis (APSGN) formed the most of glomerular hematuria and urinary system infections formed the large number of non-glomerular hematuria causes respectively.

Conclusion: This study suggests that a careful history, detailed physical examination and clinical evaluation may elucidate the etiology in most of the patients with hematuria. Advanced imaging modalities and renal biopsy are indicated only in selected cases.

Key Words: Childhood, Etiology, Hematuria

(1)

ARI ME

OZLU SG

DEMIRCIN G

CALTIK YILMAZ A

AYDOG O

BULBUL $M$
:0000-0001-7932-1074 :0000-0002-9609-1511 .0000-0002$0000-0003-0774-4410$ $.0000-0003-0774-4419$ :0000-0002-3117-5968 :0000-0001-9007-9653

Conflict of Interest / Çıkar Çatıșması: On behalf of all authors, the corresponding author states that there is no conflict of interest. Ethics Committee Approval / Etik Kurul Onayı: The study was approved by the hospital academic board.

Contribution of the Authors / Yazarların katkısI: ARI ME: Constructing the hypothesis or idea of research and/or article, Planning methodology to reach the Conclusions, Organizing, supervising the course of progress and taking the responsibility of the research/study, Taking responsibility in patient follow-up, collection of relevant biological materials, data management and reporting, execution of the experiments, Taking responsibility in lo Constructing the hypothesis or idea of research and/or article, Planning methodology to reach the Conclusions, Organizing, supervising the course of progress and taking the responsibility of the research/study, Taking responsibility in patient follow-up, collection of relevant biological materials, data management and reporting, execution of the experiments, Taking responsibility in logical interpretation and conclusion of the results, Taking responsibility in necessary literature review for the study, Taking responsibility in the writing of the whole or important parts of the study, Reviewing the article before submission scientifically besides spelling and grammar. DEMIRCIN G: Planning methodology to reach the Conclusions, Planning methodology to reach the Conclusions, Reviewing the article before submission scientifically besides spelling and grammar. CALTIK YILMAZ A: Planning methodology o reach the Conclusions, Planning methodology to reach the Conclusions, Reviewing the article before submission scientifically besides spelling and grammar. AYDOG O: Planning methodology to reach the Conclusions, Taking responsibility in logical interpretation and conclusion of the results, Reviewing the article before submission scientifically besides spelling and grammar. BULBUL M: Constructing the hypothesis or idea of research and/ or article, Planning methodology to reach the Conclusions, Organizing, supervising the course of progress and taking the responsibility of the research/ study., Taking responsibility in logical interpretation and conclusion of the results, Reviewing the article before submission scientifically besides spelling and grammar.

How to cite / Atıf yazım şekli : Ari ME, Ozlu SG, Demircin G, Caltik Yilmaz A, Aydog O, Bulbul M. Evaluation of Etiological Causes of Hematuria in Children. Turkish J Pediatr Dis 2020;14:480-487.
Correspondence Address / Yazıșma Adresi:

Sare Gulfem OZLU

Ankara Yildirim Beyazit University, Faculty of Medicine

Department of Pediatric Nephrology, Ankara, Turkey

E-posta: saredr@gmail.com
Received / Geliş tarihi : 27.07.2019 Accepted / Kabul tarihi : 11.11.2019 Online published Elektronik yayın tarihi

DOI: 10.12956/tchd.597567 


\section{öz}

Amaç: Hematüri çocuklarda üriner sistem hastalıklarının önemli bir bulgusudur. Altta yatan ciddi hastalıkların belirtisi olabileceğinden ayııcı tanı için dikkatli bir değerlendirme ve iyi bir klinik yaklaşım gerektirmektedir. Bu çalışmada pediatrik nefroloji kliniğimize hematüri nedeni ile başvuran hastaların demografik ve klinik özelliklerinin incelenmesi ve tanıya yol gösterecek özelliklerin belirlenmesi amaçlandı.

Gereç ve Yöntemler: Bu çalışma, kliniğimizde makroskopik ve/veya mikroskopik hematüri nedeniyle izlenmiş olan 370 hastanın dosyası retrospektif olarak değerlendirilerek gerçekleştirildi. Hastaların demografik verileri,laboratuar sonuçları ve klinik bulguları, görüntüleme tetkikleri ve nihai tanıları araştııılı.

Bulgular: Hastaların 195'i (\%52.7) erkek, 175 (\%47.7)'si kızdı ve çoğunluğu 6-10 yaş grubunda yer almaktaydı. Hastaların 234'ü (\%63.2) makroskopik hematüri ile başvururken, 44'ünde (\%15.3) glomerüler hematüri saptandı. Makroskopik hematüri grubunda nonglomerular nedenler anlamlı olarak yüksek bulundu. Glomerüler hematüri nedenleri arasında ülkemizde halen yaygın olarak saptanan akut poststreptokokkal glomerülonefrit (APSGN), non glomerüler nedenlerden de üriner sistem enfeksiyonu en yüksek oranda görülen hastalıkları oluşturmaktaydı.

Sonuç: Bu çalışma dikkatli bir öykü, ayrıntılı fizik muayene ve klinik değerlendirme ile hematüri ile başvuran hastaların büyük çoğunluğunda etiyolojinin aydınlatılabileceğini göstermektedir. İleri görüntüleme tetkikleri ve renal biyopsi sadece seçilmiş vakalarda endikedir.

Anahtar Sözcükler: Çocukluk Çağı, Etiyoloji, Hematüri

\section{INTRODUCTION}

Hematuria is one of the most common causes of pediatric nephrology consultation in childhood clinical practice. It is defined as the presence of blood in urine and is classified as microscopic or gross. Microscopic hematuria is defined as the presence of 3-5 erythrocytes per high power field or microliter of urine and its prevalence is 0.5-2 \% among children and adolescents. Gross hematuria is discoloration of urine due to the presence of blood and its prevalence is approximately $0.1 \%$ in children (1-5).

Hematuria may originate from upper or lower urinary tract. Upper urinary tract sources are glomerulus, tubular system or interstitium. Pelvicaliceal system, ureter, bladder or urethra are the sources of hematuria from lower urinary tract (2). In children glomerular sources are more commonly observed than the sources from lower urinary tract. The major glomerular causes of hematuria are APSGN, IgA nephropathy, thin basement membrane nephropathy (TBMN) and Alport syndrome while the major non-glomerular causes are urinary tract infections, hypercalciuria and stone disease.

Differential diagnosis of hematuria may be established with detailed history, physical examination and routine laboratory tests. Kidney biopsy is indicated for selected cases (3). We retrospectively evaluated the patients who had been followed up for gross or microscopic hematuria in our pediatric nephrology clinic.

\section{MATERIALS and METHODS}

Medical charts of 370 patients who were referred to our clinic in a period of four years with gross or microscopic hematuria were evaluated retrospectively. Demographical data of the patients, beginning and duration of the signs and symptoms, history of upper respiratory tract infection or trauma was obtained from the hospital records. Parental consanguinity, family history of chronic kidney disease (CKD), hematuria, Alport syndrome, IgA nephropathy and nephrolithiasis were recorded. Medical charts of the patients were also carefully reviewed for clinical features as hypertension, edema, rashes and upper respiratory tract infection (URTI). The study was approved by the hospital academic board.

Microscopic examination of the patients was done after centrifugation (with a rpm of 3000 for 3 minutes) and presence of five or more erythrocytes was defined as hematuria.

Routine urine examination, whole blood count, renal function tests and electrolytes, coagulation profile, complement levels, immune-globulins, hepatitis markers, anti-streptolysin $\mathrm{O}$ titers, throat and urine culture were obtained for every patient. Renal ultrasound was also performed. Antinuclear antibodies, antidouble stranded DNA antibodies; peripheral and cytoplasmic nuclear antibodies were investigated in selected patients. Computerized tomography and arteriography were performed when indicated. Ophthalmological and audiometric examination was carried out in patients who had family history of chronic kidney disease, Alport syndrome, hematuria, deafness and/ or ophthalmological problems. Renal biopsy was considered for selected cases as unidentified gross hematuria suggesting a glomerular disease, recurrent gross hematuria, microscopic hematuria with a family history of hematuria or renal disease and microscopic hematuria with proteinuria.

Family members of the patients were also evaluated for microscopic hematuria.

Patients were divided into three groups according to the clinical presentation of hematuria: Gross or macroscopic hematuria was defined as hematuria visible to the naked eye; asymptomatic isolated microscopic hematuria was defined as hematuria without any other signs or symptoms and symptomatic microscopic hematuria as hematuria accompanied by variable clinical signs.

Glomerular hematuria was defined by clinical and laboratory features as presence of hypertension, edema, systemic 
symptoms; and presence of red blood cell casts and distorted red blood cells with a ratio of more than $20 \%$; and proteinuria more than $>2+$ on dipstick evaluation respectively.

Glomerular, non-glomerular and idiopathic causes of hematuria were recorded.

Patients were classified into five groups according to their age as group 1: $0-2$ years of age, group 2: 3- 5 years of age, group 3: 6-10 years of age, group 4: 11- 15 years of age and group 5: 16 years of age and above.

We investigated whether there was any difference according to age and sex and age groups by gender in hematuria. The relationship between age, sex, hematuria pattern and course, and causes of hematuria were also evaluated.

\section{Statistical analysis}

Statistical analyzes were performed using the 'SPSS for Windows 15.0' package program (SPSS 'Statistical Package of Social Sciences' Inc., Chicago IL). The data obtained from the measurements were expressed as mean and standard deviation values; categorical data (sex, disease, etiologic group, etc.) was expressed according to the frequency (percent). Statistical evaluations were performed with a chi-square test and $p<0.05$ was considered statistically significant.

\section{RESULTS}

Three hundred and seventy patients were admitted to our nephrology clinic with hematuria in a period of four years. Mean age of the patients was $7 \pm 3.5$ years ( 4 months -17 years). One hundred and ninety-five of the patients (52.7\%) were boys and 175 (47.3\%) were girls. Although the number of boys with hematuria was greater than girls; there was not a significant difference between the two groups $(p=0.298)$.

When evaluated according to age, hematuria was more common in the age group of $6-10$ years $(p=0.001)$ and when evaluated according to gender to age it was more common among boys aged between 11 and 15 years old ( $p=0.019$ ). Table I summarizes the distribution of the patients according to the age groups.

The most common presenting feature was red colored or brown/tea colored urine (63.2\%). Abdominal pain (20.5\%),

Table I: Age groups of the patients.

\begin{tabular}{c|c|c}
\hline $\begin{array}{c}\text { Age groups } \\
\text { (years) }\end{array}$ & $\begin{array}{c}\text { Number } \\
\text { of the patients }\end{array}$ & $\begin{array}{c}\text { Percentage } \\
\text { of the patients (\%) }\end{array}$ \\
\hline $0-2$ & 27 & 7.3 \\
\hline $3-5$ & 111 & 30 \\
\hline $6-10$ & 164 & 44.3 \\
$11-15$ & 63 & 17 \\
$\geq 16$ & 5 & 1.4 \\
\hline
\end{tabular}

Table II: Presenting signs and the symptoms of the patients.

\begin{tabular}{|l|c|c|}
\hline \multicolumn{1}{|c|}{ Symptoms } & $\mathbf{n}$ & $\%$ \\
\hline Tea/brown or red colored urine & 234 & 63.2 \\
\hline Abdominal pain & 76 & 20.5 \\
\hline Dysuria & 61 & 16.5 \\
\hline Fever & 48 & 13.0 \\
\hline Vomiting & 29 & 7.8 \\
\hline Frequent urination & 26 & 7.0 \\
\hline Loin pain & 25 & 6.8 \\
\hline Swelling & 17 & 4.6 \\
\hline Sore throat & 12 & 3.2 \\
\hline Urinary incontinence & 11 & 3.0 \\
\hline Diarrhea & 10 & 2.7 \\
\hline Cough & 8 & 2.2 \\
\hline Arthalgia & 1 & 0.3 \\
\hline Rash & 1 & 0.3 \\
\hline Epistaxis & 1 & 0.3 \\
\hline Incidentally detected hematuria & 39 & 10.5 \\
\hline
\end{tabular}

dysuria (16.5\%) and fever (13\%) were also frequent symptoms at admission. In 39 (10.5\%) of the patients' hematuria was incidentally detected. Presenting symptoms are summarized in Table II.

On physical examination upper respiratory tract infection (URTI) signs were most frequently detected features. Edema, hypertension and rash were observed with a frequency of $3 \%, 0.8 \%$ and $0.5 \%$ respectively. Ocular anomalies irrelevant with Alport syndrome were detected in two of the 55 patients who underwent ophthalmological examination. Deafness was detected in three of the 58 patients and one of them was diagnosed with Alport syndrome.

Thirty-seven of the patients (10\%) had parental consanguinity. Family history of kidney disease existed in 147 (39.7\%) of the patients and the most common disorder was urolithiasis (Table III).

Two hundred and thirty-four of the patients (63.2\%) were admitted with macroscopic hematuria. Microscopic examination

Table III: Kidney diseases detected in family members.

\begin{tabular}{|c|c|c|c|c|c|}
\hline \multirow[b]{2}{*}{ Renal diseases } & \multirow[b]{2}{*}{$\mathbf{n}$} & \multirow[b]{2}{*}{$\%$} & \multicolumn{3}{|c|}{ Relatives } \\
\hline & & & $\begin{array}{c}1^{\text {st }} \\
\text { degree }\end{array}$ & $\begin{array}{c}2^{\text {nd }} \\
\text { degree }\end{array}$ & $\begin{array}{c}3^{\text {rd }} \\
\text { degree }\end{array}$ \\
\hline Urolithiasis & 106 & 72.1 & 60 & 40 & 6 \\
\hline CKD & 34 & 23.1 & 8 & 20 & 6 \\
\hline Unknown etiology & 2 & 1.3 & 1 & 1 & - \\
\hline Alport disease & 1 & 0.6 & - & 1 & - \\
\hline Others* & 4 & 2.7 & 2 & 2 & - \\
\hline Total & 147 & 100 & 71 & 64 & 12 \\
\hline
\end{tabular}

CKD: Chronic kidney disease *: Familial mediterranean fever, Behçet's disease, Renal cell carcinoma 
Table IV: Laboratory parameters at admission.

\begin{tabular}{|l|c|c|}
\hline \multicolumn{1}{|c|}{ Parameters } & $\mathbf{n}$ & $\%$ \\
\hline Anemia & 51 & 14.4 \\
\hline Thrombocytopenia & 2 & 0.6 \\
\hline Elevated BUN levels & 9 & 2.7 \\
\hline Elevated creatinine levels & 8 & 2.4 \\
\hline Hypoalbuminemia & 56 & 17.9 \\
\hline Prolonged PT & 7 & 3.7 \\
\hline Prolonged aPTT & 3 & 1.6 \\
\hline Low C3 & 28 & 10.6 \\
\hline Low C4 & 3 & 1.1 \\
\hline Elevated ASO & 32 & 17.2 \\
\hline Positive throat culture & 17 & 9.7 \\
\hline Positive urine culture & 61 & 17.9 \\
\hline
\end{tabular}

n: number, BUN: blood urea nitrogen, PT: prothrombin time, APTT: activated partial thromboplastin time; C3: complement factor 3; C4: complement factor 4; ASO: antistreptolysin O

Table V: Ultrasound findings.

\begin{tabular}{|l|c|c|}
\hline \multicolumn{1}{|c|}{ Findings } & $\mathbf{n}$ & $\%$ \\
\hline Normal & 183 & 56.7 \\
\hline Hydronephrosis & 40 & 12.4 \\
\hline Increased echogenicity & 29 & 9 \\
\hline Microlithiasis & 25 & 7.7 \\
\hline Urolithiasis & 23 & 7.1 \\
\hline Cystitis & 15 & 4.6 \\
\hline Congenital abnormalities & 5 & 1.5 \\
\hline Decreased kidney size & 2 & 0.6 \\
\hline Cyst & 2 & 0.6 \\
\hline Renal hematoma & 1 & 0.3 \\
\hline
\end{tabular}

revealed that $208(63.2 \%)$ of the patients had isomorphic, 81 (21.9\%) had dysmorphic and 81 (21.9\%) had mixed types of erythrocytes. Accompanying laboratory findings were pyuria in 52 patients (14.1\%), non-nephrotic range proteinuria in 63 patients (17\%) and nephrotic range proteinuria in two of the patients $(0.5 \%)$.

Urine calcium to creatinine ratio was high in 50 patients (15.4\%) and uric acid to creatinine ratio was high in 4 patients (2.2\%). Timed urine collection was carried out for 77 patients and 35 of them (45.5\%) had hypercalciuria and 2 of them had hyperoxaluria with hypercalciuria. Thirty-two of the patients (11.1\%) had urolithiasis. Forty percent of the patients with hypercalciuria and $43.7 \%$ of the patients with urolithiasis had a family history of stone disease. Although patients who had a family history of stone disease had a higher rate of urolithiasis and hypercalciuria this did not reach a statistically significant state $(p=0.07$ and $p=0.17$ respectively)
Table VI: Renal biopsy results.

\begin{tabular}{|l|l|l|}
\hline \multicolumn{1}{|c|}{ Findings } & n & \% \\
\hline Alport syndrome & 6 & 28.5 \\
\hline IgA nephropathy & 3 & 14.2 \\
\hline Normal & 3 & 14.2 \\
\hline MPGN & 2 & 9.5 \\
\hline Crescentic glomerulonephritis & 2 & 9.5 \\
\hline Non spesific findings & 2 & 9.5 \\
\hline APSGN & 1 & 4.7 \\
\hline PAN & 1 & 4.7 \\
\hline TBMD & 1 & 4.7 \\
\hline
\end{tabular}

n: number, IgA: Immunoglobulin A, MPGN: Membranoproliferative glomerulonephritis, TBMD: Thin Basement Membrane Disease, APSGN: Acute Poststreptococcal Glomerulonephritis, PAN: Polyarteritis nodosa

Hypocomplementemia is an important clue for diagnosis and it was observed in 31 of the patients (8.2\%). Laboratory features of the patients are summarized in Table IV.

Ultrasound was performed for 323 patients (87.3\%) and pathological findings were detected in 140 (43.3\%) of them. Hydronephrosis, hyperechogenic kidneys, microlithiasis and urolithiasis were the most common features (Table V). Doppler ultrasonography was carried out in 40 patients and revealed nutcracker syndrome in two patients.

Computed tomography was performed for only two patients and perirenal haematoma secondary to trauma was detected in one patient and obstruction of superior mesenteric artery was detected in the other one. Magnetic resonance angiography revealed minimal obstruction in left renal vein at the level of superior mesenteric artery in one patient. Intravenous pyelography was performed in 23 patients and urolithiasis was detected in two (8.7\%), hydronephrosis in $3(13 \%)$ and vascular compression in $2(8.7 \%)$ of the patients respectively.

Twenty-one patients out of 370 had undergone renal biopsy. The most common disease diagnosed by biopsy was Alport syndrome. IgA nephropathy, membranoproliferative glomerulonephritis (MPGN) and crescentic glomerulonephritis were the other common disorders detected by renal biopsy (Table VI).

Patients were divided into three groups according to the source of hematuria as glomerular, non-glomerular and idiopathic. Hematuria was non-glomerular in origin in most of the cases with a ratio of $72.4 \%$ and in glomerular origin with a ratio of 15.3 $\%$. In 35 of the patients (12.2\%) there was not any identifiable cause and they were classified as idiopathic hematuria. The most common underlying disease was urinary tract infection in $21.2 \%$ of the patients. Crystalluria (hypercalciuria, hyperoxaluria, hyperuricosuria) and urolithiasis were also common etiological factors for hematuria (Table VII). Eighty-three of the patients lost follow up so we could not be able to identify their diagnosis. 
Table VII: Diagnosis of the patients.

\begin{tabular}{|c|c|c|}
\hline Diagnosis & $\mathbf{n}$ & $\%$ \\
\hline GLOMERULAR DISEASES & 44 & 15.3 \\
\hline Primary Glomerular Diseases & 14 & 4.8 \\
\hline IgA Nephropathy & 3 & 1 \\
\hline MPGN & 2 & 0.7 \\
\hline Crescentic glomerulonephritis & 2 & 0.7 \\
\hline APSGN & 23 & 8 \\
\hline FMF & 5 & 1.7 \\
\hline PAN & 1 & 0.35 \\
\hline HSP & 1 & 0.35 \\
\hline NON-GLOMERULAR DISEASES & 208 & 72.4 \\
\hline Urinary Tract Infections & 61 & 21.2 \\
\hline hyperuricosuria & 4 & 1.4 \\
\hline hyperoxaluria & 3 & 1 \\
\hline hypercalciuria and hyperoxaluria & 2 & 0.7 \\
\hline Anatomic defects & 37 & 12.9 \\
\hline Hydronephrosis & 27 & 9.4 \\
\hline Bifid renal pelvis & 3 & 1 \\
\hline Cortical cyst & 2 & 0.7 \\
\hline Nutcracker syndrome & 2 & 0.7 \\
\hline Vesicoureteral reflux & 1 & 0.35 \\
\hline Urachus cyst & 1 & 0.35 \\
\hline Hypoplastic kidneys & 1 & 0.35 \\
\hline Coagulopathies & 9 & 3.1 \\
\hline IDIOPATHIC & 35 & 12.2 \\
\hline TOTAL & 287 & 100 \\
\hline
\end{tabular}

n: Number; IgA: Immunoglobulin A, MPGN: Membranoproliferative glomerulonephritis, TBMD: Thin Basement, APSGN: Acute Poststreptococcal Glomerulonephritis, FMF: Familial Mediterranean Fever, PAN: Polyarteritis Nodosa, HSP:Henoch Schonlein Purpura

Table VIII: Number and percentage of the patients according to the type of hematuria.

\begin{tabular}{l|c|c}
\hline \multicolumn{1}{c}{ Type of hematuria } & $\mathbf{n}$ & \% \\
\hline Asymptomatic microscopic hematuria & 39 & 10.6 \\
\hline Symptomatic microscopic hematuria & 97 & 26.2 \\
\hline Macroscopic hematuria & 234 & 63.2 \\
\hline Total & 370 & 100.0 \\
\hline
\end{tabular}

When the diagnoses were evaluated according to gender, glomerular diseases were most commonly observed among boys (18.3\%) and urinary tract infections were more frequently observed among girls $(27.6 \%)$ did not show any statistical significance" ( $p=0.057)$. Urolithiasis was the most common cause of hematuria in the age group of 0-2 years and it was detected in 8 of the patients (34.8\%). In the age groups of 3 to 5 and 6 to 10 years urinary tract infections were the most frequent etiological factors (24 patients: $27.6 \%$ and 28 patients: $22 \%$, respectively). Between the ages 11 to 16 years glomerular diseases were the most common cause of hematuria (10 patients, $21.3 \%$ ). Because the number of the patients in each 
age group was relatively limited, we could not compare the significance of this difference.

Among the patients who were presented with macroscopic hematuria non-glomerular causes were more commonly detected $(p=0.000)$. Fifty-three out of 234 patients with macroscopic hematuria lost follow up; urinary tract infections were the most common (26\%) diagnosis among the remaining 181 patients with macroscopic hematuria.

Symptomatic microscopic hematuria was detected in 97 (26.2\%) of the patients and asymptomatic microscopic hematuria was in 39 of the patients (10.6\%) (Table VIII). Glomerular diseases were the most common features in symptomatic group and urinary tract infections and urolithiasis were in the asymptomatic group.

\section{DISCUSSION}

In this report we evaluated 370 patients who were presented to our pediatric nephrology clinic with gross or microscopic hematuria. Gross hematuria is an important health concern for families and causes them to seek medical care immediately. Microscopic hematuria is often detected incidentally or during school or community screening programs and it is in fact much more common than gross hematuria (1, 6-7). In our study, gross hematuria was more frequent than microscopic hematuria (63.2 \% versus $36.8 \%$ ) and this was attributed to the anxiety of families and their immediate attempt to search medical care as mentioned above.

Contrary to previous studies which reported that hematuria was not specific for a particular age group, we detected that it was more frequently observed between age group 6 and 10 years (8). It was also more common among boys aged between 11 and 15 years old. This difference with previous studies may be related with the design of our study; we evaluated the patients who were referred to our clinic so this may not reflect the actual distribution of age.

A thorough history and physical examination is crucial to establish a differential diagnosis of hematuria. Exercise induced hematuria, urogenital trauma and coagulation deficiencies are easily detected by a careful history (1, 9). Existence of upper respiratory tract infection in the previous history may be suggestive of glomerulonephritis $(4,10)$. In according to this statement, a significant amount of our patients had URTI prior to hematuria (24.3\%); among them 18 (24\%) had various type of glomerulonephritis and 11 (14.6\%) had APSGN.

Family history of kidney disease is another important clue for diagnosis; nephrolithiasis, hereditary nephropathies, thin basement membrane disease and polycystic kidney disease are common causes of familial hematuria. In addition, presence of renal insufficiency, congenital anomalies of kidney and urinary tract (CAKUT), urolithiasis, Alport syndrome and $\lg A$ nephropathy should be sought $(9,10)$. In this report 147 of the patients had (39.7\%) a family history of kidney disease and urolithiasis was the most common feature (106 patients, 28.6 $\%)$. Patients who had family history of urolithiasis had a higher rate of stone disease and hypercalciuria but this did not reach a statistically significant state $(p=0.07$ and $p=0.17$ respectively). Although conflicting results exist in the literature $(11,12)$, we think that patients with a positive history of stone disease or hypercalciuria should be more carefully investigated in the highlight of our findings.

Careful physical examination should be carried out for patients with hematuria. Presence of hypertension, rash, abdominal mass, edema should be investigated. In patients whom particularly Alport syndrome is considered ophthalmological and audiological consultations should be repeated (13).

On laboratory evaluation microscopic examination of urine is the first step to confirm the presence and morphology of red blood cells $(3,9,10)$. Presence of $75-80 \%$ or more dysmorphic erythrocytes is highly suggestive of glomerular hematuria. A significant relationship with the morphology of erythrocytes and glomerular or non-glomerular diseases was detected in this report $(p=0.000)$. Microscopic examinations were carried out with a conventional optical microscope. Although there are contradictions in the use of conventional optical microscopy to assess the origin of hematuria recent reports revealed that it is possible to identify the morphology of erythrocytes either by conventional optical microscope or phase-contrast microscopy (14). Proteinuria; especially nephrotic range proteinuria may also be suggestive of glomerular diseases $(10,15)$. Renal biopsy may be considered earlier in this group of patients (15). In this report 63 of the patients (17\%) had non-nephrotic range and $2(0.5 \%)$ of them had nephrotic range proteinuria. Glomerular causes were detected in 23 and non-glomerular causes were detected in 36 of these patients. We could not be able to define the origin of hematuria in the other four patients. Non-nephrotic range proteinuria with hematuria in non-glomerular disorders may be explained by the hemolysis of erythrocytes in urine (3, 10).

Compromised kidney function tests are more commonly observed in glomerular hematuria than non-glomerular hematuria (15). We detected elevation in serum BUN and creatinine levels in $15.9 \%$ of patients with glomerular hematuria and $1 \%$ of nonglomerular hematuria at admission. Hypocomplementemia may also be another important clue for glomerular hematuria. Patients with APSGN, C3 glomerulopathy, SLE and shunt nephritis may present with hypocomplementemia and hematuria $(3,15)$. APSGN was detected in 23 and MPGN was detected in 3 out of 31 of our patients with hematuria and hypocomplementemia in accordance with previous reports (16).

When clinical findings suggest a non-glomerular source of hematuria imaging modalities may be used preferentially in the investigation of hematuria, ultrasonography, renal doppler 
ultrasonography, intravenous urography, multidetector computed tomography are the main techniques to evaluate non-glomerular hematuria both for children and adults (1821). Conventionally traditional radiography has been used to detect nephrolithiasis but nowadays it is mostly replaced by ultrasonography (18). In our study, ultrasonography was performed on 323 patients without classifying them according to presenting symptom as macroscopic or microscopic hematuria. Pathological findings were observed in 140 of the patients (43.3\%) and are summarized in table IV. The most common finding was hydronephrosis; microlithiasis and nephrolithiasis were also common. Only one patient had renal mass $(0.3 \%)$ on ultrasonography and he was diagnosed as neuroblastoma.

Renal doppler ultrasonography is another recommended imaging modality especially in cases of unexplained hematuria with or without abdominal pain. According to the previous reports, nutcracker syndrome (NS) is one of the leading causes of isolated hematuria in children without urinary tract infection and proteinuria and renal Doppler ultrasonography should be considered as the first screening tool for detecting NS $(20,22)$. Doppler ultrasonography was carried out for 40 of the patients in this study and nutcracker syndrome was diagnosed in one of them. Another patient had non-diagnostic signs of NS on Doppler ultrasonography, so diagnosis was confirmed by MR angiography. As mentioned above Park et al. (23) speculated that NS is an underestimated condition and it should be considered in children particularly with isolated hematuria. Shin et al. (22) detected NS in 60 out of the 149 patients with isolated hematuria. Although the number of NS is low in our study, in according to these reports we concluded that NS should be more carefully investigated in patients with hematuria.

Renal biopsy is indicated for selected patients with hematuria. Presence of family history of hematuria or nephritis, accompanying proteinuria, hypocomplementemia, nephrotic syndrome and hypertension, persistent microscopic hematuria or recurrent gross hematuria are common indications for renal biopsy $(3,10)$. Twenty-one of our patients (5.6\%) underwent renal biopsy in this study. Alport syndrome and lgA nephropathy was the two most common diseases diagnosed with renal biopsy. Although IgA nephropathy was the most common finding in the study of Lee at al.(14), frequency of the other diseases was similar with our report. We attributed this slight difference to the discrepancies of renal biopsy policies.

As mentioned before hematuria may be suggestive of glomerular or non- glomerular diseases. In our study glomerular hematuria was detected in $15.3 \%$ of the patients and non-glomerular hematuria was in $72.4 \%$ respectively. In $12.2 \%$ of the patients there was no identifiable causes, so this group was defined as idiopathic hematuria. These results are inconsistence with the previous reports $(9,17)$.
Among the patients with hematuria, urinary tract infection was the most common etiology (21.2\%). Crystalluria (13.2\%), anatomic defects (12.9\%) and urolithiasis (11.1\%) were also frequently detected. There are various frequencies reported in the literature and these discrepancies in the frequency may be attributed to the heterogeneity of the study populations $(17,24$, 25). Crystalluria is a striking feature in our study, the most common form was hypercalciuria (76.3\%). Hyperuricosuria (10.5\%), hyperoxaluria $(7.9 \%)$ and hypercalciuria with hyperoxaluria (5.2\%) were also detected. In a recent report by Spivacow et al. (25) reported hypercalciuria (43.5\%) and hypocitraturia (31.7\%) as the most common causes of asymptomatic idiopathic hematuria. They also found that although much less frequent hyperoxaluria, hypomagnesuria and hyperuricosuria may cause hematuria (25).

\section{CONCLUSION}

Hematuria is a relatively common feature in childhood. With a detailed history, physical examination and meticulous urinalysis, etiology will be identified in the most of patients. In the rest, simple laboratory and radiological examinations are compatible to establish the diagnosis. In a few patients, invasive tests such as renal biopsy may be required. The retrospective nature of the study and the fact that patients were not assessed by a single specialist were the two main limitations. Although the study was retrospective and included patients both with macroscopic and microscopic hematuria we believe that it may be informative for the common etiologies and simple diagnostic modalities of hematuria and may contribute to prevent unnecessary investigations.

\section{REFERENCES}

1. Hiren, P. Patel, John J. Bissler. Hematuria in children. Pediatric Clinics of North America 2001; 48: 6.

2. Davis ID, Avner ED. Clinical evaluation of the child with hematuria. In: Kliegman RM, Behrman RE, Jenson HB, Stanton BF (eds). Nelson textbook of pediatrics. 18th ed. Philadelphia: Saunders Elsevier 2007:2170.

3. Yap HK, Weng Lau PY. Hematuria and Proteinuria. In: Geary D, Schaefer F (eds). Comprehensive Pediatric Nephrology. 1st ed. Philadelphia: Saunders Elsevier 2008:179-84.

4. Tu WH, Shortliffe LD. Evaluation of asymptomatic, atraumatic hematuria in children and adults. Nat Rev Urol 2010; 7:189-94.

5. Shenay M, Webb NJA. Clinical Evaluation of the Child with Suspected Renal Disease. In: Avner E, Harmon W, Niaudet P, Norishige Y, Emma F, Goldstein S (eds). Pediatric Nephrology; 7th ed. 2016; p.608.

6. Cho BS, Kim SD. School urinalysis screening in Korea. Nephrology (Carlton) 2007;12: S3-7.

7. Sönmez F, Yenisey Ç, Cüce D, Ülgen H. Asymptomatic hematuria, proteinuria and pyuria in school children. Med J Ege University $1997 ; 7: 23-5$. 
8. Greenfield SP, Williot P, Kaplan D. Gross hematuria in children: a ten-year review. Urology 2007; 69:166-9.

9. Youn $\mathrm{T}$, Trachtman $\mathrm{H}$, Gauthier B. Clinical spectrum of gross hematuria in pediatric patients. Clin Pediatr (Phila) 2006; 45:13541.

10. Pan CG. Evaluation of gross hematuria. Pediatr Clin North Am 2006; 53:401-12.

11. Feld LG, Meyers KE, Kaplan BS, Stapleton FB. Limited evaluation of microscopic hematuria in pediatrics. Pediatrics 1998; 102:E42.

12. Stapleton FB, Roy S 3rd, Noe HN, Jerkins G. Hypercalciuria in children with hematuria. N Engl J Med 1984 24; 310:1345-8.

13. Rheault M.N, Kashtan CE. Inherited Glomerular Diseases. In: Avner E, Harmon W, Niaudet P, Norishige Y, Emma F, Goldstein S. Pediatric Nephrology; 7th ed 2016; p:779-795.

14. Martinez MG, dos S Silva V, do Valle AP, Amaro CR, Corrente JE, Martin LC. Comparison of different methods of erythrocyte dysmorphism analysis to determine the origin of hematuria. Nephron Clin Pract 2014; 128:88-94.

15. Wenderfer SE, Gaut JP. Glomerular Diseases in Children. Adv Chronic Kidney Dis 2017; 24:364-71.

16. Dagan R, Cleper R, Davidovits M, Sinai-Trieman L, Krause I. Post-Infectious Glomerulonephritis in Pediatric Patients over Two Decades: Severity-Associated Features. Isr Med Assoc J 2016; 18:336-40.
17. Lee JH, Choi HW, Lee YJ, Park YS. Causes and outcomes of asymptomatic gross haematuria in children. Nephrology (Carlton) 2014; 19:101-6.

18. Moloney F, Murphy KP, Twomey M, O'Connor OJ, Maher MM. Haematuria: an imaging guide. Adv Uro 2014; 2014:414125.

19. Datta SN, Allen GM, Evans R, Vaughton KC, Lucas MG. Urinary tractultrasonography in the evaluation of haematuria-a report of over 1,000 cases. Ann R Coll Surg Engl 2002; 84:203-5.

20. Park SJ, Oh JY, Shin Jl. Diagnostic value of renal Doppler ultrasonography for detecting nutcracker syndrome in children with recurrent gross hematuria. Clin Pediatr (Phila) 2012; 51:1001.

21. O'Connor OJ, McSweeney SE, Maher MM. Imaging of hematuria. Radiol Clin North Am 2008; 46:113-32.

22. Shin JI, Park JM, Lee JS, Kim MJ. Effect of renal Doppler ultrasound Pediatr 2007; 166:399-404.

23. Park SJ, Shin JI. Renal Doppler ultrasonography in the diagnosis of nutcracker syndrome. Eur J Pediatr 2013; 172:135-6.

24. Esteghamati M, Ghasemi K, Nami M. Prevalence of idiopathic hypercalciuria in children with urinary system related symptoms attending a pediatric hospital in Bandar Abbas in 2014. Electron Physician 2017; 25:5261-4.

25. Spivacow FR, Del Valle EE, Rey PG. Metabolic risk factors in children with asymptomatic hematuria. Pediatr Nephrol 2016; 31:1101-6. 